\title{
Margaret Buckingham, discoveries in skeletal and cardiac muscle development, elected to the National Academy of Science
}

\author{
Michael A Rudnicki
}

\begin{abstract}
Margaret Buckingham was presented as a newly elected member to the National Academy of Sciences on 28 April 2012. Over the course of her career, Dr Buckingham made many seminal contributions to the understanding of skeletal muscle and cardiac development. Her studies on cardiac progenitor populations has provided insight into understanding heart malformations, while her work on skeletal muscle progenitors has elucidated their embryonic origins and the transcriptional hierarchies controlling their developmental progression.
\end{abstract}

Keywords: National Academy of Sciences, Cardiac development, Skeletal muscle development

\section{Commentary}

Dr Margaret Buckingham, a much-respected investigator who has made many significant contributions to our understanding of skeletal muscle and cardiac development, was elected to the National Academy of Sciences in 2011 and presented on 28 April, 2012. Dr Buckingham is Professor in the Department of Developmental Biology at the Pasteur Institute in Paris. She has been awarded many prestigious distinctions including that of Officier de la Légion d'Honneur and Officier de l'Ordre National du Mérite, to name but two.

Dr Buckingham's early studies involved the cloning and characterization of actin and myosin genes from cardiac and skeletal muscle [1-4]. She has made seminal contributions to our understanding of cardiac development. She identified the second heart field [5] and showed its important contribution to the poles of the heart. These cardiac progenitors are regulated by a distinct genetic network and in this context, Dr Buckingham has worked on the role of fibroblast growth factor (FGF) signaling in the formation of the outflow tract and pharyngeal arteries [6]. Her studies of cardiac development revealed that that two cell lineages contribute to the myocardium [7]. Lineage studies also demonstrated a clonal relationship between arterial pole myocardium and head muscles [8].

Correspondence: mrudnicki@ohri.ca

Ottawa Hospital Research Institute, Ottawa, Ontario K1H 8 L6 Canada
Her work on cardiac progenitor populations is of clinical importance in understanding heart malformations.

Dr Buckingham has also made major contributions to the molecular genetic analysis of skeletal muscle development. She was the first to analyze expression of the myogenic regulatory factors of the MyoD family during mouse embryogenesis [9] and the behavior of cells in the absence of Myf5 [10].

Her more recent work demonstrated that skeletal muscle growth depends on a somite-derived population of progenitor cells that express Pax3 and Pax7 [11]. She established that the Myf5 gene is activated by $\operatorname{Pax} 3$ through specific regulatory elements [12], and that Pax3 regulation of FGF signaling affects the balance between progenitor self-renewal and differentiation [13]. She showed genetically that before cells acquire myogenic potential, the equilibrium between Pax3 and Foxc2 expression in the somite regulates the choice between myogenic versus vascular cell fate [14]. After demonstrating the key role of satellite cells in adult muscle regeneration [15], she investigated satellite-cell quiescence, showing recently that microRNA31 targets Myf5 mRNA, and that both are sequestered in micro-ribonucleoprotein granules which breakdown on satellite cell activation [16]. She also identified microRNA-27 as a regulator of Pax3 production [17].

Dr Buckingham's election to the academy recognizes her many significant contributions as a leading scholar in the molecular genetic study of striated muscle formation. 


\section{Competing interests}

The author declares no competing interests.

Received: 17 May 2012 Accepted: 7 June 2012

Published: 7 June 2012

\section{References}

1. Minty AJ, Alonso S, Caravatti M, Buckingham ME: A fetal skeletal muscle actin mRNA in the mouse and its identity with cardiac actin mRNA. Cell 1982, 30:185-192.

2. Robert B, Daubas P, Akimenko MA, Cohen A, Garner I, Guénet J-L, Buckingham M: A single locus in the mouse encodes both myosin light chains 1 and 3, a second locus corresponds to a related pseudogene. Cell 1984, 39:129-140.

3. Robert B, Barton P, Minty A, Daubas P, Weydert A, Bonhomme F, Catalan J, Chazottes D, Guénet J-L, Buckingham M: Investigation of genetic linkage between myosin and actin genes using an interspecific mouse back-cross. Nature 1985, 314:181-183.

4. Weydert A, Barton P, Harris AJ, Pinset C, Buckingham M: Developmental pattern of mouse skeletal myosin heavy chain gene transcripts in vivo and in vitro. Cell 1987, 49:121-129.

5. Kelly R, Brown N, Buckingham M: The arterial pole of the mouse heart forms from Fgf10 expressing precursor cells in pharyngeal mesoderm. Dev Cell 2001, 1:435-440.

6. Watanabe Y, Miyagawa-Tomita S, Vincent SD, Kelly RG, Moon AM, Buckingham ME: Role of mesodermal FGF8 and FGF10 overlaps in the development of the arterial pole of the heart and pharyngeal arch arteries. Circ Res 2010, 106:495-503.

7. Meilhac SM, Esner M, Kelly RG, Nicolas J-F, Buckingham ME: The clonal origin of myocardial cells in different regions of the embryonic mouse heart. Dev Cell 2004, 6:1-20.

8. Lescroat F, Meilhac SM, Le Garrec JF, Nicolas JF, Kelly RG, Buckingham M: Clonal analysis reveals common lineage relationships between head muscles and second heart field derivatives in the mouse embryo. Development 2010, 137:3269-3279.

9. Sassoon D, Lyons G, Wright WE, Lin V, Lassar A, Weintraub H, Buckingham M: Expression of two myogenic regulatory factors myogenin and MyoD1 during mouse embryogenesis. Nature 1989, 341:303-307.

10. Tajbakhsh S, Rocancourt D, Buckingham M: Muscle progenitor cells failing to respond to positional cues adopt non-myogenic fates in myf-5 null mice. Nature 1996, 384:266-270.

11. Relaix F, Rocancourt D, Mansouri A, Buckingham MA: A Pax3/Pax7dependent population of skeletal muscle progenitor cells. Nature 2005, 2005:435,948-953.

12. Bajard L, Relaix F, Lagha M, Rocancourt D, Daubas P, Buckingham ME: A novel genetic hierarchy functions during hypaxial myogenesis: Pax3 directly activates Myf5 in muscle progenitor cells in the limb. Genes Dev 2006, 20:2450-2464

13. Lagha M, Kormish JD, Rocancourt D, Manceau M, Epstein JA, Zaret KS, Relaix F, Buckingham ME: Pax3 regulation of FGF signaling as embryonic progenitor cells progress into the myogenic program. Genes Dev 2008, 22:1828-1837.

14. Lagha M, Brunelli S, Messina G, Kume T, Relaix F, Buckingham ME: Pax3/7: Foxc2 reciprocal repression in the somite modulates multipotent stem cell fates. Dev Cell 2009, 17:892-899.

15. Montarras D, Morgan J, Collins C, Relaix F, Zaffran S, Cumano A, Partridge T, Buckingham M: Direct isolation of satellite cells for skeletal muscle regeneration. Science 2005, 309:2064-2067.

16. Crist C, Montarras D, Buckingham M: Muscle satellite cells are primed for myogenesis, but maintain quiescence with sequestration of Myf5 mRNA targeted by microRNA-31 in mRNP granules. Cell Stem Cell 2012, In Press.

17. Crist CG, Rocancourt D, Montarras D, Buckingham M: Muscle stem cell behaviour is modified by microRNA-27 regulation of Pax3 expression. Proc Natl Acad Sci USA 2009, 106:13383-13387.

\section{doi:10.1186/2044-5040-2-12}

Cite this article as: Rudnicki: Margaret Buckingham, discoveries in skeletal and cardiac muscle development, elected to the National Academy of Science. Skeletal Muscle 2012 2:12.

\section{Submit your next manuscript to BioMed Central and take full advantage of:}

- Convenient online submission

- Thorough peer review

- No space constraints or color figure charges

- Immediate publication on acceptance

- Inclusion in PubMed, CAS, Scopus and Google Scholar

- Research which is freely available for redistribution 